\title{
GREEN MARKETING APPLICATION STRATEGY FOR INCREASING CONSUMER SATISFACTION \\ (CASE STUDY IN FAST FOOD BUSINESS COMPANY GROUP AT MALL KARAWANG)
}

\author{
Oleh :
}

Rieke Retnosary, ST., MM

\section{Abstract}

Green marketing is not something new in business. Nowdays, environmental issues become the best opportunity in the marketing strategy. Awearness about environtmental and save the earth become one chance from our responsibility.

Environmental damage has become everybody concern, including unit business interst fast food at Karawang Mall. In practice, not all units conducting green issues, but most consumer producst using packaging that can biodegrade in a shoorter time.

Research purposes to obtain empirical evidence and find clarity phenomena and conclusions about Green Marketing Strategy For Increasing Customer Satisfaction Case Study In Fast Food Business Company Group At Mall Karawang espacially in environmantally friendly food packaging.

This research is expected to contribute to the develpment of economics, especially marketing management. Research conducted on 60 speakers as costumers at fast food group at Mall Karawang using qualitative methods with a naturalistic approach. Data is narrative, descriptive, field notes according to interviews and dokumentation, and make conclusions and recomendations.

The results of the analysis of research data, it is concluded as follows :

1. Application of green marketing strategies carried out by business in the Mall Karawang were overlooked by the customers due to perceived lack of information.

2. Customer satisfaction is not obtained from the application of the strategy management of green marketing fast food business group at Mall Karawang but service strategy and menu options.

3. Customers tend to come back even if green marketing strategy is not done because of three basic lean namely; taste, price, and prestige.

4. Factors which become obstacles in the implemantation of green marketing strategy for customers is that customera do not understand the importance of the strategy undertaken by the management to maintain environtmental balance. This is due to a lack of understanding of management information to customers is not done continously/ constantly.

The results of this study, given some recommandations to the fast food business group in Mall Karawang.

Key words : green marketing, implementation of strategy green marketing, eco-friendly food packaging, customer satisfaction.

\section{Latar Belakang}

Membangun nilai kepuasan, dan loyalitas pelanggan dalam proses penawaran produk tidak terlalu sulit jika dilakukan dengan strategi pemasaran yang tepat dalam mengatur suatu organisasi atau suatu perusahaan, karena hal tersebut merupakan inti dari kegiatan usaha.

Beberapa perusahaan atau pengusaha memposisikan pelanggan di tempat yang utama dari model pelayanannya. Dalam model diagram modern urutan posisi strategi dimulai dari mengutamakan pelanggan, pegawai yang bertugas di posisi paling depan, manajemen menengah, dan diakhiri oleh manajemen teratas (Kotler. 2009:135). 
Lingkungan hidup telah menjadi sebuah isu strategis yang penting. Pemanasan global, bioterorisme, dan polusi yang meningkat menunjukkan bahwa kini tidak ada ancaman yang lebih besar terhadap usaha dan masyarakat melebihi eksploitasi dan perusakan lingkungan hidup yang tiada henti (Fred R. David. 2012 : 4). Angga Bhagya wartawan Warta Kota menuliskan Indeks lingkungan hidup Indonesia menurut Balthasar Kambuaya (Menteri Lingkungan Hidup) dalam acara pemberian sertifikasi Ecolebel pada PT Chandra Asri Petrochemical Tbk (CAP) di Jakarta Pusat, Rabu (19/3/2014) adalah pada posisi 112 dari 178 negara. Indeks tersebut berdasarkan beberapa indikator diantaranya kualitas udara, iklim, energi, tutupan hutan, dan pengelolaan air. Pembukaan pekan lingkungan hidup pada hari kamis di Balai Kartini, Jakarta, Balthasar pun mengatakan bahwa kualitas air kurang, kebanyakan tercemar, luas tutupan hutan masih sedikit, dan sampah yang dihasilkan banyak.

Rendahnya peringkat Indonesia dalam penanggulangan lingkungan hidup dari upaya pencemaran, membuat sikap-sikap pengelolaan industri terhadap lingkungan harus semakin ditingkatkan.

Peluang inilah yang mendasari pengusaha mengambil keputusan untuk beralih pada isu lingkungan, termasuk dalam usaha makanan dengan makanan sehat dan kemasan ramah lingkungan. Kegiatan usaha yang ramah lingkungan, seringkali dilupakan. Maka inisiatif pemasaran produk usaha menuju hijau atau Go Green dipilih sebagai strategi usahanya.

Pemasaran Hijau / Green marketing sudah banyak dilakukan oleh beberapa pengusaha namun belum dilakukan secara menyeluruh. Contohnya Hoka hoka Bento (HokBen) awal penggunaan pembungkus makanan mengandung styrofoam yang dapat terurai setelah 100-500 tahun, tapi sekarang bisa terurai lebih cepat menjadi 4 tahun karena mengandung Oxium. Perusahaan ini masih menggunakan sedotan plastik, sendok dan garpu plastik namun pada dasarnya sudah cukup dapat mengurangi volume sampah yang nantinya akan mengganggu lingkungan.

Mini market (Alfamart, Indomart, Giant) telah menyiapkan kantung berupa tas bertuliskan "GO GREEN" yang bertujuan untuk meminimalkan penggunaan plastik bagi barang bawaan pembeli. Nilai dan gaya hidup memiliki pengaruh positif pada prilaku ramah lingkungan.

Hasil uji regresi yang dilakukan oleh Suprihatin Ali, dosen jurusan Administrasi Bisnis Fisip Universitas Lampung dalam jurnal Perspektif bisnis,Vol. 1, No. 1, Juni 2013 didapatkan bahwa nilai dan gaya hidup dalam diri konsumen menjadi faktor penting yang harus diperhatikan oleh praktisi pemasaran dalam hal ini pemasar produk ramah lingkungan.

Terlepas dari apa yang menjadi produk unggulan bagi pengusaha dalam kegiatan usahanya, pemerintah Indonesia mengharapkan dan mewajibkan setiap kegiatan yang dilakukan harus mengacu pada pengelolaan lingkungan hidup. Undang-Undang Republik Indonesia No. 32 Tahun 2009 tentang Perlindungan dan pengelolaan lingkungan hidup dalam poin a menimbang bahwa lingkungan hidup yang baik dan sehat merupakan hak asasi setiap warga negara Indonesia sebagaimana diamanatkan dalam Pasal 28H UndangUndang Dasar Negara Republik Indonesia Tahun 1945.

Izin lingkungan bagi kegiatan usaha diberikan penjelasan dalam peraturan pemerintah Republik Indonesia No. 27 Tahun 2012 sesuai dengan amanah pasal 33 ayat (4) yang berbunyi, "proses pembangunan yang dilakukan oleh bangsa Indonesia harus diselenggarakan berdasarkan prinsip pembangunan berkelanjutan dan berwawasan lingkungan".

Penerapan sanksi administratif di bidang perlindungan dan pengelolaan lingkungan hidup tertuang dalam Peraturan Menteri Lingkungan Hidup Republik Indonesia No. 02 Tahun 2013, sedangkan pencantuman logo ekolebel diatur oleh peraturan Menteri Lingkungan Hidup No. 02 Tahun 2014.

Penelitian ini dilakukan di tempat keramayan yang menyediakan seluruh aktivitas yang dicari oleh masyarakat baik sarana berbelanja ataupun konsumsi berupa makanan dan minuman di Mall Karawang. Dan penelitian dilakukan hanya pada kemasan/ pembungkus makanan dan minuman di Restoran siap saji. Berdasarkan latar belakang, peneliti membuat judul penelitian "Penerapan Strategi Green Marketing Dalam Upaya Meningkatkan Kepuasan Pelanggan (Studi Kasus Kelompok Usaha Makanan Siap Saji di Mall Karawang)".

\section{Perumusan Masalah}

Rumusan masalah yang didapat dari fenomena-fenomena di latar belakang adalah :

1. Bagaimana penerapan strategi pemasaran hijau yang dilakukan manajemen kelompok usaha makanan siap saji di Mall Karawang. 
2. Bagaimana penerapan strategi pemasaran hijau kelompok usaha makanan siap saji di Mall Karawang menurut pelanggan.

3. Bagaimana tingkat kepuasan pelanggan dari strategi pemasaran hijau yang diterapkan oleh kelompok usaha makanan siap saji di Mall Karawang.

4. Faktor-faktor apa saja yang menjadi kendala dalam pemasaran hijau Kelompok usaha makanan siap saji di Mall Karawang.

\section{Tujuan Penelitian}

Tujuan dari penelitian adalah mengidentifikasi dan menganalisis :

1. Penerapan strategi pemasaran hijau yang dilakukan manajemen kelompok usaha makanan siap saji di Mall Karawang.

2. Penerapan strategi pemasaran hijau kelompok usaha makanan siap saji di Mall Karawang menurut pelanggan.

3. Tingkat kepuasan pelanggan dari strategi pemasaran hijau yang diterapkan oleh kelompok usaha makanan siap saji di Mall Karawang.

4. Faktor-faktor yang menjadi kendala dalam pemasaran hijau Kelompok usaha makanan siap saji di Mall Karawang.

\section{Kerangka Pemikiran}




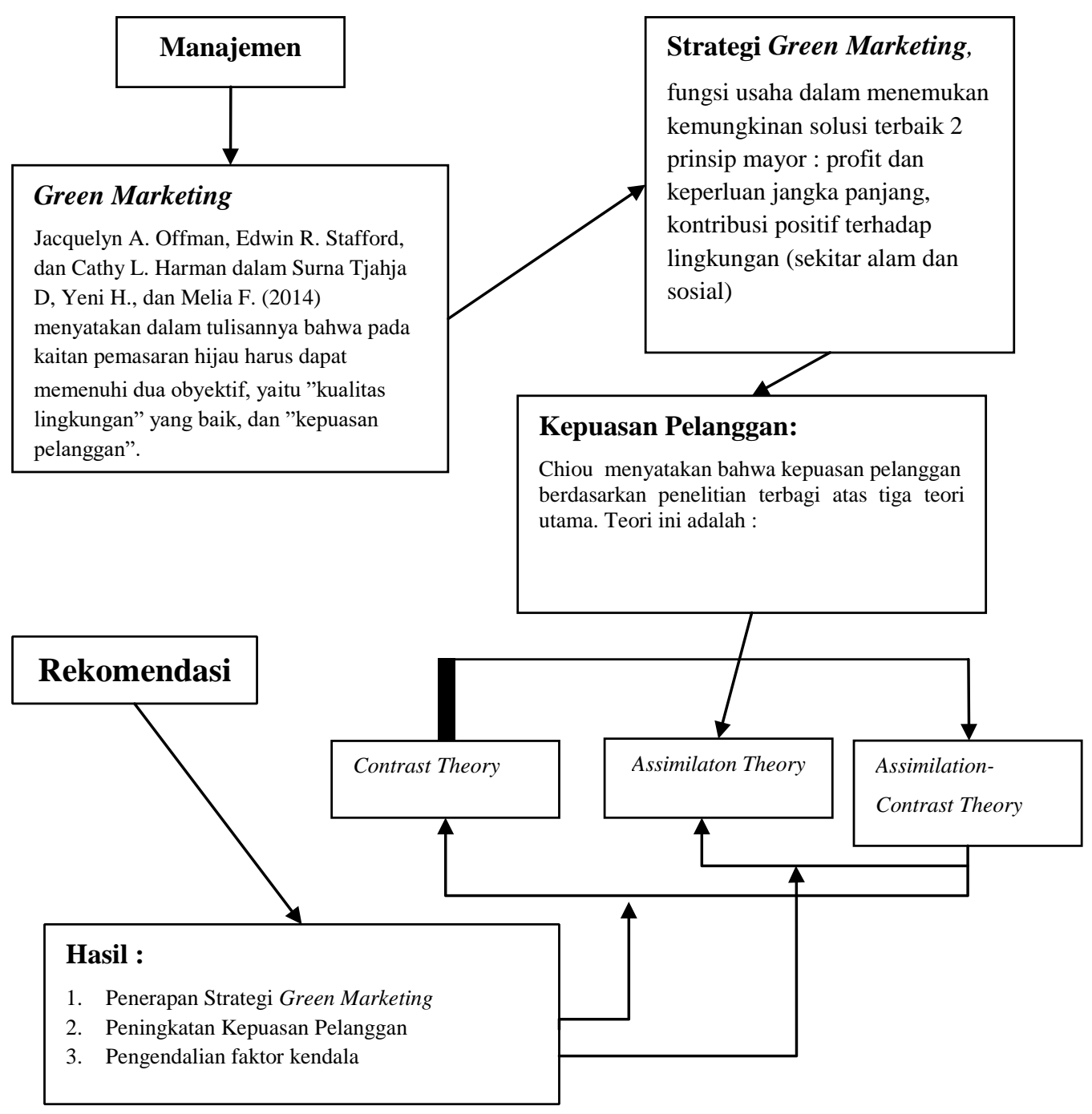

Gambar 5.1 Diagram Kerangka Pemikiran

\section{Tinjauan Pustaka}

\subsection{Strategi Pemasaran}

Manajemen Pemasaran Strategis (David A. Aaker. 2013 : 13-17) adalah sebuah sistem yang dirancang untuk membantu manajemen menciptakan, mengubah, atau mempertahankan sebuah strategi usaha dan untuk menciptakan visi strategis. Visi strategis adalah sebuah proyeksi dari sebuah strategi di masa depan atau seperangkat strategi.

Dalam kegiata pemasaran, manajemen harus memiliki strategi tertentu untuk mengetahui pasar. Kegiatan yang dilakukan adalah menganalisis setiap bagian yang akan membantu pencapaian tujuan. Analisis yang dilakukan dinamakan analisis strategi. Analisis strategi terbagi atas analisis eksternal dan analisis internal. Kegiatan strategi memiliki tujuan-tujuan tertentu (David A. Aaker.2013 : 17 -18).

Tujuan- tujuan manajemen pemasaran strategis adalah :

1. Mengedepankan pertimbangan dari pemilihan strategis

2. Membantu sebuah usaha untuk dapat mengatasi perubahan

3. Mendorong sebuah pandangan yang jauh

4. Membuat keputusan pengalokasian sumber daya menjadi nyata

5. Membantu analisis strategis dan pengambilan keputusan

6. Memberikan sebuah manajemen strategis dan sistem kendali

7. Memberikan sistem komunikasi dan koordinasi dan koordinasi horizontal dan vertikal. 


\subsection{Kepuasan Pelanggan}

Dalam Fandi Tjiptono \& Gregorius Chandra (2011 : 105, 292 - 298) menuliskan bahwa kepuasan pelanggan adalah salah satu kegiatan hasil analisis internal yang dilakukan oleh suatu perusahaan/ organisasi. Kepuasan pelanggan merupakan bagian dari kebijakan dan strategi produk dalam ruang lingkup manajemen pemasaran. Cakupan kebijakan dan strategi produk salahsatunya adalah strategi pengembangan produk dimana diharapkan dapat terwakilinya keinginan dan harapan pelanggan.

Kepuasan (satisfaction) berasal dari bahasa latin "satis" (artinya cukup baik, memadai) dan "facio" (melakukan atau membuat).

Menurut Schanaars (Fandi Tjiptono. 2011: 298), tujuan sebuah bisnis adalah menciptakan para pelanggan yang puas, sedangkan Chiou menyatakan bahwa kepuasan pelanggan berdasarkan penelitian terbagi atas tiga teori utama. Teori ini adalah :

1. Contrast Theory

2. Assimilation Theory

3. Assimilation-contrast Theory

\subsection{Pemasaran Hijau (Green Marketing) dan Strategi Hijau (Green Strategy)}

Calomarde dalam Judianto Hasan (2014 : 215) pada buku Riset Pemasaran dan Konsumen seri 2, menuliskan bahwa pertimbangan ekologi merupakan variabel yang relevan untuk mencapai tujuan ekonomis dari perusahaan telah menuju pada suatu konsep marketing baru, yaitu green marketing.

Marija Ham (2013) menuliskan bahwa pemasaran hijau pertamakali didefinisikan oleh American Marketing Association dari topik workshop environmental marketing 1975 yang dinamakan : "The Study of positive and negative aspects of marketing activities on polution, energy deplettion, and depletion of non-energy resources" (Bors. 2004: 65).

Sebagai strategi, pemasaran hijau menyiratkan kerjasama antara supplier dan penjual, partner-rival, untuk menerima pembangunan lingkungan secara berkelanjutan melalui seluruh perubahan nilai, dimana dalam waktu yang bersamaan, di dalam panggilan dari kerjasama semua fungsi usaha dalam menemukan kemungkinan solusi terbaik 2 prinsip mayor : profit dan keperluan jangka panjang, kontribusi positif terhadap lingkungan (sekitar alam dan sosial).

Alasan perusahaan meningkatkan pemakaian green marketing salah satunya adalah perusahaan menerima environmental marketing menjadi suatu kesempatan yang dapat digunakan untuk meraih tujuantujuan.

\subsection{Standar Pengelolaan Lingkungan}

ISO 14000 adalah standar pengelolaan lingkungan yang dikeluarkan oleh International Organization for standardization (ISO). (H.B. Iswanto. 2005: 204)

Banyaknya manfaat yang dapat diperoleh atas adanya pengelolaan lingkungan. Secara umum manfaat sertifikasi ISO 14000 adalah : 1. Perlindungan terhadap lingkungan;

2. Dasar persamaan kompetitif;

3. Menunjukkan kesesuaian dengan peraturan;

4. Pembentukan sistem pengelolaan yang efektif;

5. Penurunan biaya;

6. Penurunan kecelakaan kerja;

7. Peningkatan hubungan masyarakat

8. Peningkatan kepercayaan dan kepuasan konsumen

9. Peningkatan perhatian manajemen.

Peraturan Menteri Lingkungan Hidup Republik Indonesia No. 2 Tahun 2014 telah membuat standar bagi perusahaan atau badan usaha yang menginginkan standar ramah lingkungan bagi usahanya dengan pencantuman logo Ekolebel yang ditetapkan di Jakarta pada tanggal 24 Januari 2014 dan diundangkan pada tanggal 5 Pebruari 2014. 


\subsection{Kemasan Ramah Lingkungan}

Indonesia Solid Waste Association (InSWA) dan Badan Pengkajian dan Penerapan Teknologi (BPPT) mengembangkan dan pemperbaiki program Green Label Indonesia (GLI). Untuk produk kemasan yang berhasil mendapatkan sertifikasi Green Label Indonesia adalah Oxium dan Ecoplas (plastik dari pati singkong), produk plastik ramah lingkungan produksi PT Tirta Marta. Kantong plastik yang menggunakan Oxium dapat terurai sekitar 2 tahun dan Ecoplas yang merupakan plastik biodegradable dapat terurai hanya dalam waktu 6 bulan jika syarat degradasi alamiahnya terpenuhi. Telah menggunakan plastik ini mayoritas perusahaan ritel besar. (Budi PrasetyoTribunnews.Com Jakarta.2014)

\section{Hasil dan Pembahasan}

\subsection{Hasil Penelitian}

Penelitian berfokus pada Strategi Green Marketing/ Strategi Pemasaran Hijau yang diterapkan oleh kelompok usaha makanan siap saji di Mall Karawang untuk pemasaran produknya dalam upaya meningkatkan kepuasan pelanggan.

Pada saat dilakukan observasi di lapangan, peneliti lebih memperhatikan pada pembungkus/ kemasan, termasuk didalamnya alat-alat bantu konsumsi produk kelompok usaha makanan siap saji di Mall karawang, karena dianggap merupakan faktor pendukung strategi pemasaran yang mempengaruhi lingkungan/ ramah lingkungan (Go Green).

Hasil analisis data merupakan konklusi (conclusions) dari data yang telah direduksi setelah dikumpulkan (Collection) dan yang tersedia (display), dimana data yang didapat berasal dari 5 (lima) restoran yang tersedia, terdiri atas HokBen, Pizza Hut, KFC, Solaria, dan Rice Bowl. Pelanggan yang diwawancarai adalah 83 (delapanpuluh tiga) sebagai narasumber, namun dalam pengolahan data direduksi menjadi tiga (tiga) tempat yaitu HokBen, Pizza Hut, dan KFC, karena Solaria dalam pengolahan bahan baku untuk menjadi menu produk penawaran tidak dikategorikan sebagai makanan siap saji, sedangkan Rice Bowl, tidak cukup informasi yang dapat diambil baik secara langsung pada pihak manajemen karena keengganan manajemen pusat untuk menerima penelitian dalam bentuk apapun, maupun tidak langsung (website, promosi, dan lainnya) dan ketika dilakukan pengkategorian makanan siap saji, Rice Bowl tidak termasuk, sehingga dalam kegiatannya, Solaria, Rice Bowl, dan termasuk wawancara pada pelanggan sebagai narasumber tidak dijadikan bahan kajian. Jumlah pelanggan yang menjadi bahan kajian hanya 60 (enampuluh) narasumber yang langsung berhubungan dengan tiga tempat tersebut.

Teknik penelitian dilakukan adalah triangulasi, sehingga dapat dikonfirmasi antara informasi manajemen terhadap pelanggan dan begitu juga sebaliknya.

Untuk teknik pengambilan data, dilakukan observasi di HokBen, KFC, dan Pizza Hut, serta wawancara dilakukan pada pihak manajemen HokBen dan pelanggan sebagai narasumber ke tiga tempat sebagai kelompok usaha di Mall Karawang.

Dari hasil penelitian yang dilakukan di Mall Karawang, peneliti membandingkan dengan perumusan masalah yang telah dibuat dan didapatkan hasil sebagai berikut :

\subsubsection{Penerapan Strategi Pemasaran Hijau Oleh Manajemen}

Penerapan strategi pemasaran hijau yang dilakukan oleh manajemen kelompok usaha makanan siap saji di Mall Karawang tidak benar-benar dilakukan. Terlihat dari kemasan yang disiapkan oleh manajemen untuk keperluan pelanggan terutama KFC.

KFC dalam informasi website miliknya mengajak pelanggan untuk meminimalkan penggunaan kemasan pada produk konsumsi, green action dengan slogan "We Do Because We Care", tetapi kenyataan yang terjadi di restoran KFC sendiri, semua kemasan yang digunakan habis pakai dan menjadi tumpukan sampah. Mulai dari kemasan makanan, minuman, sedotan, alat makan, semua mengandung plastik dan styrofoam kecuali piring dan penyediaan tisu. Piring dapat digunakan kembali karena dapat dibersihkan/ dicuci. Tisu yang disiapkan, tidak diberikan pada pelanggan secara berlebihan. Plastik kemasan yang disiapkan untuk bawa pulang (take a way), tidak memiliki lebel green.

Kondisi berbeda dilakukan oleh HokBen dan Pizza Hut. HokBen telah menyediakan produk kemasan yang ramah lingkungan. Plastik yang disiapkan untuk pelanggan telah berlebel green dan dapat terurai setelah 24 
bulan ( 2 tahun) karena mengandung Oxium. Tempat makan untuk take a way atau pesan antar (delivery), juga telah mengandung Oxium sehingga dapat terurai dalam jangka 4 tahun. Lamanya kemasan ini terurai karena kemasan tersebut mengandung styrofoam. Jika pesanan dibawa pulang disiapkan wadah kemasan dan pembungkus plastik dengan green lebel dikeluarkan oleh InSwa dengan IGL No. 010110-002 yang telah menggunakan Oxium (dapat mengurai plastik 2 tahun dan 4 tahun untuk kemasan berisi nasi, menu penawaran). Bekerja sama dengan produk minuman mineral yang menggunakan kemasan botol plastik yang dapat di recycle.

Pemakaian alat makan dan kemasan dalam proses konsumsi di HokBen sedikit berbeda dengan di KFC. HokBen menyiapkan alat makan lebih banyak, yaitu pelanggan disiapkan sendok, garpu, dan sumpit untuk konsumsi yang menurut peneliti adalah suatu pemborosan, karena semua alat tersebut habis pakai. Alas makan pengganti piring, mangkuk penyajian sup dapat digunakan kembali karena dapat dicuci. Sedotan dan kemasan minuman (botol plastik air mineral) juga menjadi sampah. Kemasan botol plastik air mineral ini berhubungan dengan rekanan usaha. Minuman yang disediakan oleh HokBen untuk pelanggan, ada yang menggunakan kemasan plastik habis pakai dan ada yang menggunakan gelas biasa (kaca). Penggunaan tisu, pelanggan dapat mengambil di tempat penyimpanan saus dan sedotan, sehingga penggunaan bergantung pada kebutuhan pelanggan. Strategi ini menjadi baik, jika pelanggan yang tidak merasa butuh, tidak menggunakannya. Program go green selain penggantian kemasan adalah upaya CSR dan Earth Hour sebagai kegiatan penyelamatan bumi. Contohnya : penanaman pohon di pusat yang diinformasikan ke semua cabang HokBen, setiap tahun dilakukan Earth Hour 2-3 jam (mematikan lampu/ pengurangan penggunaan listrik, mengurangi pemakaian air) dengan tujuan mengurangi panas bumi, efisiensi biaya, dan air. Informasi kepada pelanggan dalam Earth Hour ini adalah dengan standing banner, poster, media sosial.

Earth Hour yang dilakukan di cabang merupakan instruksi pusat. Kegiatan Earth Hour selain terdiri dari pemadaman lampu di restoran HokBen di berbagai tempat, hemat penggunaan air, juga penggunaan tempat makan yang dibawa dari rumah oleh pelanggan untuk mengurangi sampah. Terakhir dilakukan kegiatan pada tanggal 22 Maret 2014 dan Earth Hour ini selalu dilakukan setiap tahun sebagai hari bumi.

Pizza Hut memiliki produk sampah yang lebih sedikit, karena alat bantu konsumsi yang disiapkan dapat digunakan kembali, seperti piring, gelas, garpu, sendok, dan mangkuk salad. Tempat penyajian produk konsumsi juga dapat digunakan kembali. Yang terlihat oleh peneliti, sampah yang dihasilkan hanya sedotan, tisu, kotak salad untuk take a way, dan plastik pembungkus berlebel green untuk sisa makanan untuk di bawa pulang. Kotak pizza kecil dan besar jika take a way dapat langsung dihancurkan/ diurai. Untuk pemesanan take away atau sisa konsumsi dan delivery, pihak manajemen menyiapkan kotak pizza satuan dan dus berukuran untuk pizza utuh. Kotak atau dus ini merupakan kertas tebal yang dapat mudah dihancurkan. Jika makanan lainnya, manajemen sudah menyiapkan kotak salad kecil berbahan dasar plastik khusus menyimpan makanan, tetapi untuk minuman menggunakan bahan dasar plastik. Pembungkus pesanan berupa plastik yang juga berlebel green seperti di HokBen dengan nomor IGL yang berbeda. Dapat disimpulkan bahwa, konsumsi dalam restoran jauh lebih ramah lingkungan dibandingkan pemesanan untuk take away atau delivery.

Hasil wawancara langsung dengan 60 pelanggan tentang sampah hasil konsumsi, didapatkan bahwa posisi kelompok usaha yang memproduksi sampah dari yang terbanyak sampai yang sedikit secara berurutan menurut pelanggan adalah :

1. KFC

2. HokBen

3. Pizza Hut

\subsubsection{Penerapan Strategi Pemasaran Hijau Menurut Pelanggan}

Data pelanggan yang berhubungan dengan ramah lingkungan (go green), diterjemahkan dalam tabel 4.1

Tabel 4.1

Pengetahuan Pelanggan Terhadap Ramah Lingkungan

\begin{tabular}{|c|c|l|c|}
\hline No. & Pelanggan & \multicolumn{1}{|c|}{ Informasi } & Keterangan \\
\hline 1. & 43 & Belum pernah & - \\
\hline 2. & 7 & Pernah & Tidak menjelaskan \\
\hline
\end{tabular}




\begin{tabular}{|l|l|l|l|}
\hline 3. & 10 & Pernah & Penjelasan sesuai dengan pemahamannya \\
\hline
\end{tabular}

\subsubsection{Tingkat Kepuasan Pelanggan}

Tingkat kepuasan pelanggan dari strategi pemasaran hijau yang diterapkan oleh kelompok usaha makanan siap saji di Mall Karawang bukan didasari dari penerapan strategi green marketing. Karena dari hasil wawancara didapatkan data, 43 dari 60 pelanggan sebagai narasumber lebih memilih KFC karena dianggap lebih murah, sesuai selera, cepat saji/ tidak terlalu lama menunggu sekalipun mereka harus antri melakukan pemesanan dan juga lebih praktis. Suasana di restoran KFC dianggap lebih nyaman dan makanannya cukup mengenyangkan. 5 dari 60 narasumber memilih HokBen sesuai selera dan juga nyaman. 1 dari 60 memilih Pizza Hut karena prestisius. 3 dari 60 narasumber terkadang datang ke KFC atau HokBen dengan alasan sesuai selera, cepat, dan praktis. 3 dari 60 narasumber memilih KFC dan Pizza Hut dengan alasan penyajian cepat, padahal untuk pizza sendiri membutuhkan sekitar 20 menit untuk disajikan. 5 dari 60 memilih ketiganya yaitu, HokBen, KFC, dan Pizza Hut dengan alasan penyajian cepat, pelayan ramah, citra merk yang baik (prestise), dan sesuai selera.

Hasil data tersebut, dimasukkan pada data tabel 4.2

Tabel 4.2

Pilihan Pelanggan Terhadap Produk Makanan Siap Saji

\begin{tabular}{|l|l|c|}
\hline No. & Kelompok Usaha & Jumlah pelanggan yang memilih \\
\hline 1. & HokBen & 5 \\
\hline 2. & KFC & 43 \\
\hline 3. & Pizza Hut & 1 \\
\hline 4. & HokBen, KFC & 3 \\
\hline 5. & KFC, Pizza Hut & 3 \\
\hline 6. & HokBen, KFC, Pizza Hut & 5 \\
\hline & Jumlah Pelanggan & 60 \\
\hline
\end{tabular}

Keputusan pelanggan pada produk ramah lingkungan dibandingkan dengan produk yang dikonsumsi sekarang ini dan hasilnya dapat dilihat pada tabel 4.3

Tabel 4.3

\begin{tabular}{|c|c|l|l|}
\hline No. & $\begin{array}{l}\text { Jumlah pelanggan } \\
\text { yang memilih }\end{array}$ & \multicolumn{1}{|c|}{ Keputusan } & $\begin{array}{l}\text { Keputusan Pelanggan Terhadap Produk } \\
\text { Dari } 8 \text { pelanggan yang akan beralih pada produk } \\
\text { lebih ramah lingkungan, hanya 2 saja yang } \\
\text { menjadikan ramah lingkungan sebagai gaya hidup } \\
\text { (green living). }\end{array}$ \\
\hline 1. & 8 & $\begin{array}{l}\text { Beralih pada produk } \\
\text { yang lebih ramah } \\
\text { lingkungan }\end{array}$ \\
\hline 2. & 52 & $\begin{array}{l}\text { Tetap pada produk yang } \\
\text { sekarang dikonsumsi }\end{array}$ \\
\hline
\end{tabular}

\subsubsection{Faktor-faktor Kendala Dalam Pemasaran Hijau}

Faktor-faktor yang menjadi kendala dalam pemasaran hijau Kelompok usaha makanan siap saji di Mall Karawang adalah:

1. Informasi

Pihak manajemen dari salah satu produk makanan siap saji yaitu HokBen merasa sudah memberikan informasi kepada pelanggan ketika mengubah/ mengganti kemasan. Hanya saja informasi ini tidak dilakukan secara terus-menerus atau berkesinambungan sehingga tidak dapat dipahami oleh pelanggan yang lain atau baru karena mereka datang ke restoran setelah informasi dilakukan. Konfirmasi kepada narasumber sebagai pelanggan yang dipetakan pada tabel 4.1, mereka merasa tidak pernah mendapatkan informasi apapun tentang konsumsi hijau, ramah lingkungan dan sejenisnya dari pihak manajemen, salah satu narasumber yang bisa 
menjadi contoh adalah penikmat HokBen, KFC, dan Pizza Hut menjawab bahwa dia tidak pernah mendapatkan informasi apapun tentang ramah lingkungan baik go green, strategi green marketing, green living, dan sebagainya. Mereka sekarang ini melakukana penyadarkan diri sendiri untuk hidup lebih sehat dan lebih ramah lingkungan. Harapan untuk manajemen adalah produk yang dihasilkan harus lebih ramah lingkungan, sehingga pelanggan tidak terlalu kesulitan jika ingin mengonsumsi atau menggunakan produkproduk yang ditawarkan. artinya, narasumber sebagai pelanggan berharap, ketika mereka menggunakan produk tersebut sudah diyakinkan bahwa tidak mengganggu lingkungan.

2. Kurangnya kesadaran

Dalam suatu kesempatan, peneliti menunjukkan pembungkus plastik yang memiliki green lebel (mengandung Oxium) dan tidak ada tanda green lebel kepada beberapa pelanggan yang diwawancarai, ternyata mereka tidak terfikirkan sama sekali untuk mengetahui lebih jauh sebelumnya. Mereka hanya berfikir manfaat jangka pendek saja dari penggunaan karena mereka tidak tahu pentingnya mengetahui dan memahami hal tersebut. Pemetaan terhadap prilaku pelanggan yang kurang kesadaran dalam memperhatikan dampak lingkungan ini terdapat pada tabel 4.3

\subsection{Pembahasan Penelitian}

Pembahasan yang didapatkan proposisi dengan hasil penelitian adalah :

\subsubsection{Penerapan Strategi Pemasaran Hijau Oleh Manajemen}

Penerapan strategi pemasaran hijau yang dilakukan manajemen kelompok makanan siap saji di Mall Karawang belum dilakukan secara menyeluruh dalam kegiatannya, memiliki kesamaan antara proposisi dengan hasil penelitian. Pada tabel 4.1 dapat terlihat ketidakterkaitan antara manajemen dengan pelanggan mengenai strategi pemasaran hijau yang ramah lingkungan. Karena pelanggan merasa tidak pernah mendapat informasi langsung dari pihak manajemen. Sedangkan pihak manajemen merasa telah memberikan informasi. Ini mengindikasikan tidak adanya kesinambungan atau terus menerusnya informasi manajemen kepada pelanggan. Dalam ruang lingkup pemasaran (Paul Mali dalam Sofjan Assauri. 2011:14) terdapat kebijakan dan strategi promosi yang mencakup edvertensi, strategi promosi penjualan (sales promotion), strategi personal seling, dan strategi publisitas serta komunikasi pemasaran, yang ternyata pada kegiatan lapangan sudah dilakukan oleh semua kelompok usaha makanan siap saji di Mall Karawang baik di media audio visual (televisi), papan iklan ataupun pada tempat mereka sendiri (restoran) namun tidak satupun promosi produk/ kemasan hijau atau ramah lingkungan yang dilihat oleh peneliti. Peneliti hanya mendapat informasi dari manajemen bahwa mereka pernah mensosialisasikan kemasan mereka yang lebih ramah lingkungan.

\subsubsection{Penerapan Strategi Pemasaran Hijau Menurut Pelanggan}

Penerapan strategi pemasaran hijau kelompok usaha makanan siap saji di Mall Karawang belum cukup dipahami oleh sebagian pelanggan, karena hasil penelitian menunjukkan kepuasan pelanggan bukan berasal dari strategi pemasaran hijau melainkan dari tiga hal yaitu selera, harga dan prestise. Sesuai tabel 4.2 yang memperlihatkan data pilihan pelanggan terhadap produk makanan siap saji di Mall Karawang.

\subsubsection{Tingkat Kepuasan Pelanggan}

Tingkat kepuasan pelanggan dari strategi pemasaran hijau yang diterapkan oleh kelompok usaha makanan siap saji di Mall Karawang belum dapat diukur karena dipengaruhi oleh pemahaman pelanggan. Tabel 4.2 menunjukan keputusan pelanggan bukan berdasar pada strategi tersebut, melainkan strategi yang lain sehingga pelanggan merasa puas.

Dalam Fandi Tjiptono \& Gregorius Chandra (2011: 105) menuliskan bahwa kepuasan pelanggan adalah salah satu kegiatan hasil analisis internal yang dilakukan oleh suatu perusahaan/ organisasi. Kepuasan pelanggan merupakan bagian dari kebijakan dan strategi produk dalam ruang lingkup manajemen pemasaran.

Strategi produk yang dilakukan oleh kelompok usah makanan siap saji di Mall Karawang terlihat hanya pada produk konsumsi yang ditawarkan pada pelanggan, dan ini berhubungan langsung dengan ekspektasi atau harapan pelanggan sehingga dalam kegiatan konsumsi, pelanggan merasa puas atau tidak puas.

Pemahaman dari pemberian informasi menjadikan pelanggan sebagai narasumber berada pada pilihannya sesuai dengan tabel 4.3 
Uji keabsahan data terdiri atas transferabilitas, depenabilitas dan konfirmabilitas. Kegiatan ini dituliskan oleh peneliti dimulai dari poin 4.1 sampai dengan 4.3 pada bab ini. Dari data-data tabel 4.1 sampai dengan 4.3 , jika dihubungkan dengan kepuasan pelanggan, peneliti mengasumsikan teori yang dipakai cenderung pada asimilasi (assimilation theory) sesuai teori menurut Chiou, karena ketika terjadi penerimaan penyimpangan/ pebedaan dari ekspektasi atau harapan pelanggan untuk strategi pemasaran hijau, pelanggan cenderung tidak memperhatikan dan kembali pada ekspektasi awal (bukan dari pola ramah lingkungan).

\subsubsection{Faktor-faktor Kendala Dalam Pemasaran Hijau}

Beberapa kendala dalam pemasaran hijau kelompok usaha makanan siap saji di Mall Karawang cukup dirasakan pelanggan sehingga dapat menghambat pembelian produk tersebut, tidak ditemukan dalam proses penelitian. Peneliti tidak menemukan kendala yang mempengaruhi kegiatan konsumsi melainkan kendala yang didapatkan adalah :

1. Informasi

Informasi yang diberikan pada pihak manajemen restoran kelompok makanan siap saji di Mall Karawang tidak dilakukan secara berkesinambungan. Padahal dalam kegiatan pemasaran, informasi produk sangat mempengaruhi peluang pasar jika produsen dalam hal ini kelompok makanan siap saji di Mall Karawang ingin melakukan perubahan atau diversifikasi produk.

Kebijakan dan strategi promosi yang mencakup strategi advertensi, strategi promosi penjualan (sales promotion), strategi personal seling, dan strategi publisitas serta komunikasi pemasaran (dalam teori ruang lingkup manajemen pemasaran, poin 10 hal. 18) dalam pengenalan green marketing atau kegiatan/ produk ramah lingkungan tidak dilakukan.

\section{Kurangnya kesadaran}

Kurangnya kesadaran pelanggan dalam perilaku ramah lingkungan. Pelanggan hanya berfikir manfaat jangka pendek saja dari penggunaan karena mereka tidak tahu pentingnya mengetahui dan memahami hal tersebut.

Hasil positif dari wawancara yang dilakukan, paling tidak pelanggan mengharapkan manajemen dari kelompok usaha makanan siap saji dapat berfikir untuk mencari inovasi yang tepat agar kemasan/ pembungkus makanan serta alat bantu konsumsi yang mereka produksi atau miliki dapat lebih ramah lingkungan (rekomendasi pelanggan). Beberapa dari 60 pelanggan sebagai narasumber, dapat memperbaiki perilaku menjadi positif terhadap kegiatan ramah lingkungan. Memperhatikan dan dapat membedakan produk-produk yang ramah lingkungan dan yang tidak ramah lingkungan (pemberian informasi secara langsung dapat mengubah sedikitnya 1,2, atau lebih pelanggan menghormati lingkungan).

\section{Kesimpulan dan Rekomendasi}

\subsection{Kesimpulan}

Dari hasil penelitian dan pembahasan, didapatkan kesimpulan :

1. Penerapan strategi pemasaran hijau yang dilakukan oleh manajemen kelompok usaha makanan siap saji di Mall Karawang, belum cukup diperhatikan oleh pelanggan karena dianggap kurang informasi.

2. Kepuasan pelanggan didapat bukan dari penerapan strategi pemasaran hijau manajemen kelompok usaha makanan siap saji di Mall Karawang melainkan strategi pelayanan dan menu pilihan

3. Pelanggan cenderung akan datang kembali sekalipun strategi pemasaran hijau tidak dilakukan karena bersandar dari tiga dasar yaitu; selera, harga, prestise.

4. Faktor-faktor yang menjadi kendala dalam penerapan strategi pemasaran hijau bagi pelanggan adalah karena pelanggan belum memahami pentingnya peran strategi yang dilakukan oleh pihak manajemen untuk menjaga keseimbangan lingkungan. Kurangnya pemahaman ini disebabkan informasi manajemen kepada pelanggan tidak dilakukan secara berkesinambungan/ terus-menerus.

\subsection{Rekomendasi}

Rekomendasi peneliti diberikan pada: 


\subsubsection{Manajemen kelompok usaha makanan siap saji di Mall Karawang :}

1. jika pemasaran hijau ingin dipahami sebagai strategi yang pro-lingkungan sehingga pelanggan mengerti dan memahami, maka yang harus dilakukan adalah promosi informasi yang harus lebih sering dan dapat diketahui seluruh pelanggan.

Contohnya adalah,

a. Standing Banner yang dipasang di restoran mempromosikan pro-lingkungan

b. Dinding restoran sehingga dapat dibaca oleh pelanggan sambil pelanggan mengonsumsi makanan di restoran

c. Selebaran menu yang ditambahkan informasi bahwa manajemen sangat memperhatikan lingkungan.

d. Seragam yang mencirikan kepedulian tentang lingkungan.

e. Maskot yang memperkenalkan pelanggan pada pembelajaran lingkungan.

2. pengurangan alat bantu konsumsi yang habis pakai kemudian dibuang. 
Contonya adalah,

a. Sedotan plastik yang sebetulnya bisa dihindari, karena rata-rata orang Indonesia di rumahnya tidak menggunakan sedotan untuk minum dari gelas.

b. Pemilihan antara sendok plastik, garpu plastik dan sumpit kayu yang diberikan pada pelanggan sehubungan dengan menu yang dikonsumsi.

c. Pengurangan konsumsi untuk di bawa pulang atau pesan antar, jika tidak dimungkinkan menggunakan kemasan yang ramah lingkungan.

\subsubsection{Pelangga makanan siap saji di Mall Karawang}

Pelanggan harus selektif dalam pemilihan produk, karena pemilihan produk dengan baik dapat memberikan kualitas hidup lebih baik. Terutama dengan pemilahan produk yang ramah lingkungan. Pemilahan produk ramah lingkungan dapat memperlambat kerusakan bumi. Pelanggan harus memperhatikan hal-hal, seperti :

1. Pemasaran hijau yang dilakukan oleh kelompok usaha makanan siap saji harus dijadikan referensi bagi penyelamatan lingkungan sekecil apapun.

2. Penggunaan kemasan/ pembungkus yang tidak ramah lingkungan sesedikit mungkin saat konsumsi atau membeli suatu produk yang diinginkan.

3. Jadikan kepuasan dilihat dari faktor dampak lingkungan.

4. Biasakan makan di tempat/ restoran (tidak dibawa pulang).

\section{Daftar Pustaka}

\subsection{Buku dan Jurnal}

Angga Bhagya. 2014. Warta Kota. Jakarta

Buchari Alma. 2011. Manajemen Pemasaran \& Pemasaran Jasa. p. 130

David A. Aaker. 2013. Manajemen Pemasaran Strategi. Salemba Empat. Jakarta. p. 25, 26, 31,32

Edwina Luck\& Ayu Ginanti. 2013. Online Environmental Citizenship: Blogs, Green Marketing and Consumer Sentiment in the 21st Century. Electronic Green Journal

Eko Sutriyanto. 2011. InSWA. Tribunnews.com. Jakarta.

Fabian Durif \& Jean Roy. Could Percaived Risks Explain The "Green Gap" In Green Product Consumtion Electronic Green Journal

Fandy Tjiptono \& Gregorius Chandra. 2011. Service, Quality \& Satisfaction. ANDI. Yogyakarta. p. 105, 292 - 298

Fred R. David. 2012. Manajemen Strategi Konsep. Salemba. Bandung. p. $198-203$

H.B. Iswanto. 2005. Pengantar Manajemen, Bumiaksara. p. 204

Lexy J. Moleong. 2014. Metodologi Penelitian Kualitatif. Remaja Rosda Karya. Bandung. P . 4-6, 35, 330-332

Manongko, Allen A. Ch. 2011. Tesis. Green Marketing Dan Pengaruhnya Terhadap Keputusan Pembelian Melalui Minat membeli Produk Organik.

Marija Ham. 2013. Environtmentally Oriented Marketing Communications As Part Of Green Marketing Strategy

Marsella Yeanette Hatane, Adinda Yosari \& Felicia Christiana H. 2011 .Evaluation of the Successfulness of $A$ Green Program through Customer Perceived Quality, Brand Image, and Customer Satisfaction: A Case Study at Surabaya Plaza Hotel

Md. Saiful Islam. \& Iffat Zabin. 2013. Consumer's Attitude towards Purchasing Green Food. European Journal of Business and Management

Michael Jay Polonsky. 1994. An Introduction To Green Marketing. Electronic Green Journal

Philip Kotler \& Kevin Lane Keller. 2009. Manajemen Pemasaran. Erlangga. Jakarta. P. 135

Ratih Tresnati. 2004. Pengaruh Kinerja Pemasaran Dan Lingkungan Individu Terhadap keputusan Pembelian Serta Dampak Pada Nilai Pelanggan. Disertasi.UNPAD.

Rudi Haryadi. 2009. Tesis. Pengaruh Strategi Green Marketing Terhadap pilihan konsumen melalui Pendekatan Marketing Mix (Stusi Kasus pada The Body Shop, Jakarta)

Situmorang, R. James. 2011. Pemasaran Hijau Yang Semakin Menjadi Kebutuhan Dalam Dunia Bisnis. Jurnal administrasi bisnis 
Suprihatin Ali.2013. Prediksi Perilaku Ramah Lingkungan Yang Dipengaruhi Oleh Nilai Dan Gaya Hidup Konsumen.

Sugiyono.2012. Metode Penelitian Kuantitatif, Kualitatif dan R\&D. Alfabeta. Bandung. P. 217-219, 246-252, 276277

Susatyo Herlambang. 2013. Pengantar Manajemen, Cara Mudah Memahami Ilmu Manajemen. Gasyen. Sofjan.Assauri. 2011. Manajemen Pemasaran. Dasar, Konsep \& Strategi.

$$
\begin{aligned}
& \text { | } \mathrm{P} \text { a g e } \\
& \text { p. } 12,13
\end{aligned}
$$

\subsection{Peraturan, Kebijakan, dan Buku Pedoman}

Undang-undang Perlindungan \& Pengelolaan Lingkungan Hidup. 2013. Fokusindo Mandiri. Band 